\title{
Microbial Safety of Dairy Manure Fertilizer Application in Raspberry Production
}

\section{OPEN ACCESS}

Edited by:

Eugenia Bezirtzoglou,

Democritus University of Thrace,

Greece

Reviewed by:

Beatriz Quiñones,

United States Department of

Agriculture-Agricultural

Research Service, United States

Jincai Ma,

Jilin University, China

Gerardo Leotta,

National Council for Scientific and Technical Research (CONICET),

Argentina

*Correspondence:

Mei-Jun Zhu

meijun.zhu@wsu.edu

Specialty section:

This article was submitted to

Food Microbiology,

a section of the journal

Frontiers in Microbiology

Received: 18 June 2019 Accepted: 18 September 2019 Published: 02 October 2019

Citation:

Sheng L, Shen X, Benedict C, Su Y, Tsai H-C, Schacht E, Kruger CE, Drennan M and Zhu M-J (2019) Microbial Safety of Dairy Manure Fertilizer Application in Raspberry Production.

Front. Microbiol. 10:2276. doi: 10.3389/fmicb.2019.02276

\author{
Lina Sheng ${ }^{1}$, Xiaoye Shen ${ }^{1}$, Chris Benedict ${ }^{2}$, Yuan Su', Hsieh-Chin Tsai', \\ Elizabeth Schacht ${ }^{2}$, Chad E. Kruger ${ }^{3}$, Margaret Drennan ${ }^{4}$ and Mei-Jun Zhu ${ }^{1 *}$
}

'School of Food Science, Washington State University, Pullman, WA, United States, 'Whatcom County Extension, Washington State University, Bellingham, WA, United States, ${ }^{3}$ Center for Sustaining Agriculture and Natural Resources, Washington State University, Pullman, WA, United States, ${ }^{4}$ Natural Resources Assessment Section, Washington State Department of Agriculture, Olympia, WA, United States

Dairy manure, a by-product in the dairy industry, is also a potential source of nutrients for crops. However, improper application of biological soil amendments of animal origin can be a source of contamination with enteric foodborne pathogens. A 2-year field study was conducted to evaluate impacts of dairy manure fertilizer application on the microbial safety of red raspberry (Rubus idaeus L) production. Fertilizers, including a standard synthetic fertilizer (CON), straight lagoon raw manure (SL), anaerobically digested liquid effluent (DLE), compost (COM) and dairy manure-derived refined fertilizers including ammonium sulfate (AS) and phosphorous solid (PS), were randomly applied in quadruplicate to raspberry plots. Soil, fertilizer, foliar, and raspberry fruit samples were collected during the cropping season for the quantification of indicator microorganisms (total coliform and generic Escherichia coli) and detection of important foodborne pathogens (Shiga toxinproducing E. coli (STEC), Salmonella, and Listeria monocytogenes). Counts of total coliforms in soil were stable over the 2017 cropping season and were not impacted by fertilizer application. In 2018, total coliforms increased with season and soils treated with COM had a significantly higher coliform number than those treated with CON. Both total coliform and generic $E$. coli in raspberry fruit samples were below the detectable level (3 most probable number/g) regardless of fertilizer types. In both years, no STEC or L. monocytogenes was detected from any of the collected samples regardless of fertilizer treatments. However, Salmonella were detected in some of the fertilizers, including PS (2017), DLE (2018), and SL (2018), which were transferred to soil samples taken directly after application of these fertilizers. Salmonella were not detected in soil samples 2 or 4 months post fertilizer application, foliar, or raspberry fruit samples regardless of fertilizer applications. In summary, one-time application of raw dairy manure or dairy manurederived fertilizers more than 4 months prior to harvest has no major impact on food safety of red raspberry (6 ft. tall) production in Lynden sandy loam under good agricultural practices.

Keywords: raspberry, fertilizer, soil, foliar, indicator microorganisms, pathogenic microorganisms 


\section{INTRODUCTION}

Dairy-derived fertilizers are high in nutrients such as nitrogen and phosphate and can increase organic matter content in soil and subsequently improve soil fertility and physical properties such as aggregation, resistance to water or wind erosion, and water-holding capacity (Carter and Stewart, 1995; Rechcigl, 1995; Zebarth et al., 1999). Application of dairy manure-derived fertilizers in a raspberry field can enhance plant root growth and nutrient acquisition (Forge et al., 2014). However, raw manure potentially carries different pathogens such as Shiga toxin-producing Escherichia coli (STEC), Salmonella spp., and Listeria spp. (Hutchison et al., 2005), which are three major pathogens frequently involved in fresh produce outbreaks. A high level of $2.6 \times 10^{8} \mathrm{CFU} / \mathrm{g}$ of E. coli O157:H7 was detected in fresh cattle manure (Hutchison et al., 2004). The National Organic Program (7 CFR \$205.203) requires that raw animal manure must be composted before application to crops for human consumption or incorporated into the soil more than 120 days prior to harvest for produce whose edible portion has direct contact with soil or 90 days prior to harvest for crops that have no direct contact with soil (CFR, 2019). The Produce Safety Rule under Food Safety Modernization Act (FSMA) also emphasizes that the application of raw manure must not contact produce during application and the potential for contact with produce after application should be minimized (FDA, 2019b). Federal Regulations (21CFR122.55) further specified the microbial standards for biological soil amendments of animal origin including less than 0.3 most probable number $(\mathrm{MPN})$ per gram or milliliter of analytical portion for E. coli O157:H7, less than 3 MPN per $4 \mathrm{~g}$ or $\mathrm{ml}$ of total solids for Salmonella spp., and less than 1 colony-forming unit per $5 \mathrm{~g}$ or $\mathrm{ml}$ of analytical portion for L. monocytogenes (FDA, 2018b).

Therefore, prior to field application, dairy manure is commonly subjected to different treatments such as composing (FDA, 2018a) and anaerobic digestion (Wilkie, 2005) to reduce pathogen level and meet the above microbiological standards. The prediction of pathogen reduction during manure handling and field application is difficult due to the lack of lab or pilot field studies and various influencing factors such as temperature, duration, $\mathrm{pH}$, and moisture (Sobsey et al., 2006). Previous studies have also reported the persistence and survival of pathogens during manure treatments such as storage, piling, composting, and anaerobic digestion (Grewal et al., 2007; Resende et al., 2014), posing risk to the safety of fresh produce production systems. During manure application, the potential incorporated pathogens can further be transferred to soil, which also serves as a reservoir of foodborne pathogens (Natvig et al., 2002; Islam et al., 2004b, 2005; Mootian et al., 2009), or even directly contaminate the fresh produce through aerosols under harsh weather such as strong winds (Baertsch et al., 2007). It was reported that E. coli O157:H7 (Islam et al., 2004a) and S. Typhimurium (Islam et al., 2004b) persisted for more than 200 days in soil amended with composts. Survival of pathogens in soil is further influenced by soil type (Jechalke et al., 2019). Pathogens in soil can be transferred to fresh produce grown in contaminated soil (Hirneisen et al., 2012; Eissenberger et al., 2018; Jechalke et al., 2019). Therefore, raw manure and manure-derived fertilizers can become a contamination source to introduce pathogenic bacteria into fresh produce, causing serious foodborne outbreaks. Dairy manure was identified as a potential contamination source for the 2018 multistate outbreak of E. coli O157:H7 linked to romaine lettuce (210 cases and 5 deaths) (CDC, 2018a). A multistate E. coli O157:H7 outbreak associated with spinach due to dairy manure infected over 200 people and caused three deaths in 26 states (Grant et al., 2008).

Berries are grown in open environments and subjected to pathogenic microorganism contamination during production (Macori et al., 2018; Tefera et al., 2018). Raspberry and raspberry products have been involved in outbreaks and recalls associated with human norovirus (Sarvikivi et al., 2012; CFIA, 2017; FDA, 2019a,c) and Cyclospora cayetanensis (Herwaldt et al., 1997; Ho et al., 2002). Fresh blueberries were involved in a Salmonella Newport outbreak in Minnesota, 2010 (Miller et al., 2013). In addition, raspberries are usually not subjected to any antimicrobial treatment before packing or being consumed as fresh berry due to the delicate and complicated structure. Any contamination in a raspberry field, including improperly treated compost or raw manure, irrigation water, soil, and wild or domestic animals (Beuchat, 2002), can pose a threat to food safety and human health. Foodborne pathogens L. monocytogenes, Salmonella spp., and STEC particularly E. coli O157:H7 have been frequently involved in various fresh produce outbreaks (Grant et al., 2008; CDC, 2011, 2012; FDA, 2014) and are of the greatest public health concerns. However, to our knowledge, no document exists regarding the potential risk of the above three foodborne pathogens during raspberry production. Once pathogens are introduced to raspberries, Salmonella and E. coli O157:H7 were able to survive on raspberry at $4^{\circ} \mathrm{C}$ for at least 10 days ( $\mathrm{Xu}$ and $\mathrm{Wu}, 2016)$. Therefore, it is of great importance for the raspberry industry to evaluate the microbiological safety of the current production. The objective of this study was to assess the microbial risk of dairy manure fertilizer application in a red raspberry cropping system.

\section{MATERIALS AND METHODS}

\section{Field Experimental Design}

The field experiment was conducted in a 4.79-acre commercial red raspberry (Rubus idaeus L) field located in Whatcom County, Washington State in 2017 and 2018. The red raspberries were grown on Lynden sandy loam, a common soil type for red raspberries grown in this area, which is a deep and well-drained soil. The field was planted to the floricane fruiting variety "Meeker," the most common red raspberry variety for the processing industry. This commercial raspberry farm had been managed similarly since its planting in 2011. Floricanes are removed annually after fruiting in the fall or winter and trained to a trellis. Bare soil (Lynden sandy loam) is maintained below plants for the application of fertilizers. Individual plot $(22.86 \mathrm{~m} \times 3.05 \mathrm{~m})$ contains one row of 
raspberry plant. There is a buffer row between treatments ( $6.10 \mathrm{~m}$ buffer between treatment rows) to isolate plots and prevent cross-contamination.

Treatments included a standard synthetic granular fertilizer (CON) acquired from a local fertilizer dealer, aerobically composted diary manure (COM) purchased from a local compost company that uses local dairy manure as a feedstock, raw manure straight lagoon (SL) and anaerobically digested diary manure products including digested liquid effluent (DLE), phosphorous solids (PS) and ammonium sulfate (AS) that were collected from one local dairy farm. Fertilizers extracted from anaerobic digestion were previously summarized in Benedict et al. (2018). Briefly, after anaerobic digestion of SL and subsequent physical separation of low-nutrient fibrous solids, PS is extracted from the remaining effluent using centrifuge or dissolved air flotation systems. AS is derived from the manure products post-PS extraction through ammonia stripping process. DLE is the liquid portion of manure that had passed through the anaerobic digestion. Physiochemical properties including moisture, $\mathrm{pH}$, and nutritional information of each fertilizer are summarized in Table 1. CON was applied using standard sidedischarge fertilizer spreader and the product was placed into a $0.06 \mathrm{~m}$ band beneath the raspberry plants. AS was applied by $\mathrm{CO}_{2}$ backpack sprayer. COM and PS were hand-applied. DLE and SL were applied using custom in-row manure spreader. The fertilizers were applied based on agronomic rates (nitrogen (N)/acre for AS, COM; phosphorus (P) for DLE, PS, SL; nitrogen-phosphorus-potassium (NPK) for CON). We were shooting to deliver the same total NPK based on what the growers considered "standard" for their cropping systems. All fertilizers were applied once per season following good agricultural practices. Plots were setup in a completely randomized design with four replications per fertilizer treatment. The plots were irrigated with well water using two buried drip lines.

\section{Sampling Plan}

Sampling plan is outlined in Figure 1. Fertilizers were sampled before application in late March; five samples were collected per fertilizer in 2017 and four samples per fertilizer in 2018. CON was sampled from 5-gallon buckets with 8-10 subsamples ( $\sim 50 \mathrm{~g} /$ subsample) per sample. COM and PS were piled $(\sim 3 \mathrm{~m}$ $\times 3 \mathrm{~m}, 1.2 \mathrm{~m}$ height) and collected in plastic bags from different

TABLE 1 | Physiochemical properties of tested fertilizers.

\begin{tabular}{|c|c|c|c|c|c|c|}
\hline \multirow{2}{*}{$\begin{array}{l}\text { Ferti- } \\
\text { lizer }\end{array}$} & \multirow{2}{*}{$\begin{array}{c}\text { Moisture } \\
(\%)\end{array}$} & \multicolumn{2}{|c|}{ Nitrogen } & \multirow{2}{*}{$\begin{array}{l}\text { Phosphorus } \\
\left(\mathrm{g} \mathrm{P}_{2} \mathrm{O}_{5} / \mathrm{kg}\right)\end{array}$} & \multirow{2}{*}{$\begin{array}{l}\text { Potassium } \\
\left(\mathrm{g} \mathrm{K}_{2} \mathrm{O} / \mathrm{kg}\right)\end{array}$} & \multirow[t]{2}{*}{ pH } \\
\hline & & $\mathrm{NH}_{4}(\mathrm{~g} / \mathrm{kg})$ & Total N (g/kg) & & & \\
\hline $\mathrm{CON}$ & / & 210 & 210 & 440 & 500 & / \\
\hline AS & 100.0 & 52.4 & 50.3 & 0.002 & 0.01 & 1.77 \\
\hline $\mathrm{COM}$ & 69.5 & 1.8 & 21.5 & 12.8 & 18.5 & 8.02 \\
\hline DLE & 96.5 & 1.5 & 2.5 & 0.4 & 1.8 & / \\
\hline PS & 70.3 & 4.7 & 32.4 & 31.6 & 11.3 & 8.62 \\
\hline SL & 95.6 & 0.9 & 1.8 & 0.3 & 2.8 & / \\
\hline
\end{tabular}

Values are averaged from 12 samples/fertilizer over the 2-year study (6 samples/year, $n=12$ ). /: not measured; CON: standard fertilization; AS: ammonium sulfate; COM: compost; DLE: digested liquid effluent; PS: phosphorous solid; SL: straight lagoon. locations of the pile with $8-10$ subsamples ( $~ 50 \mathrm{~g} /$ subsample) taken from three depths per location. For liquid or slurry fertilizers (AS, DLE, SL), samples were collected in 1-L polypropylene bottles from different location of the holding tank. Soil samples were collected before fertilizer application, right after fertilizer application, and 2 months post-application (1 month pre-harvest), and 1 month post-harvest (Figure 1). Two samples were collected per plot with 20 subsamples per sample ( 500 g/sample) using a soil core sampler $(2.5 \mathrm{~cm}$ diameter $)$ from a depth of $0-5 \mathrm{~cm}$ (EPA, 2014). Foliar samples ( 100 g/sample, $\sim 50$ leaves) were collected in brown paper bags in triplicate per plot for 2017 study and in duplicate per plot for 2018 study before fruit harvest. Fully expanded leaves devoid of disease or any other damage were picked all over the canopy ( $\sim \mathrm{m}$ off the ground) including primocane and floricane leaves. Raspberry fruits of commercial maturity were sampled on the day prior to the beginning of commercial harvest. Three samples ( 100 g/sample, $\sim 30$ raspberries) were randomly collected from 10 different areas or bushes per plot. The above samples were transported on ice in an insulated cooler to Food Microbiology laboratory and analyzed within $24 \mathrm{~h}$.

\section{Quantification of Indicator Microorganisms}

Bacteria of enteric origin such as generic E. coli and total coliforms are commonly used as indicator microorganisms to assess the potential presence of fecal contamination in water and compost (EPA, 2012; Danyluk et al., 2013). However, coliforms are reported as a poor indicator for fresh fruits and vegetables because they are part of the normal microbiota (Danyluk et al., 2013). Suitability of total coliforms and generic E. coli as fecal indicator microorganisms were assessed in the raspberry production system. Total coliforms and generic E. coli were enumerated by both direct plating and 3-tube MPN (FDA, 2002). Briefly, $25 \mathrm{~g}$ of representative sample was homogenized in $225 \mathrm{ml}$ of buffered peptone water [BPW, Becton, Dickinson and Company (BD), Sparks, MD]. The resulting bacterial suspension was serially diluted and spread onto duplicate CHROMagar ECC (CHROMagar, Paris, FR) plates and incubated at 30 and $44.5^{\circ} \mathrm{C}$ for $24 \mathrm{~h}$ for direct enumeration of total coliform and generic E. coli, respectively. The limit of detection (LOD) for the plating method is $10 \mathrm{CFU} / \mathrm{g}$. For MPN estimation, $1 \mathrm{ml}$ of the above bacterial suspension was transferred to three tubes containing $9 \mathrm{ml}$ of lauryl tryptose broth [LST, Hardy Diagnostics (HD), Santa Maria, CA] with a Durham tube. LST tubes were incubated at $35^{\circ} \mathrm{C}$ for $24-48 \mathrm{~h}$ for gas and turbidity. Gas-positive turbid tubes were further transferred with a sterile loop to brilliant green lactose bile broth (BGLB, HD) and E. coli broth with 4-methylumbelliferyl$\beta$-D-glucuronide (EC + MUG, HD) for the confirmation of total coliform and generic $E$. coli, respectively. BGLB tubes were incubated at $35^{\circ} \mathrm{C}$ for $24-48 \mathrm{~h}$. EC + MUG tubes were incubated at $44.5^{\circ} \mathrm{C}$ for $24 \mathrm{~h}$. Turbid BGLB tubes with gas production were considered coliform positive. Turbid EC + MUG tubes with gas production and fluorescence under a long-wave UV lamp were considered generic E. coli positive. MPN results were interpreted according to Bacteriological Analytical Manual (BAM) (FDA, 2010). The LOD for MPN method is $3 \mathrm{MPN} / \mathrm{g}$. 


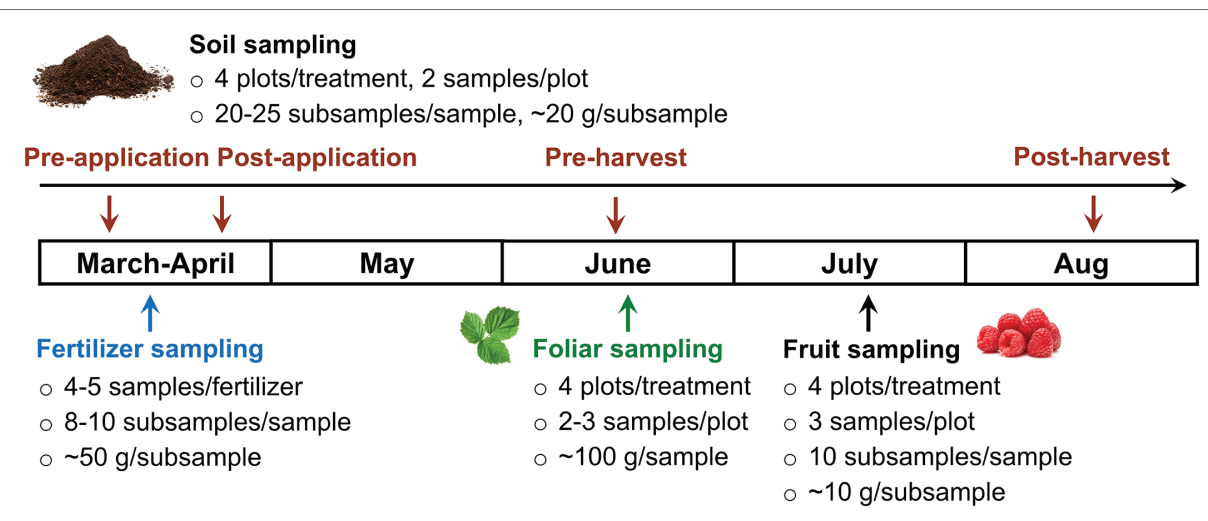

FIGURE 1 | Microbiological sample collection plan in 2017 and 2018 cropping seasons.

\section{Detection of Shiga Toxin-Producing E. coli}

STEC were detected using both standard plating method and multiplex PCR (Feng et al., 2011). Briefly, $25 \mathrm{~g}$ of representative sample was homogenized in $225 \mathrm{ml}$ of modified BPW with $0.1 \%$ $(\mathrm{w} / \mathrm{v})$ pyruvate (Amresco, Solon, $\mathrm{OH}$ ), incubated at $35^{\circ} \mathrm{C}$ for $5 \mathrm{~h}$, then supplemented with selective reagents to final concentrations of $10 \mathrm{mg} / \mathrm{L}$ acriflavin (TCI America, Portland, OR), $10 \mathrm{mg} / \mathrm{L}$ cefsulodin (Sigma-Aldrich, St. Louis, MO), and $8 \mathrm{mg} / \mathrm{L}$ vancomycin (Sigma-Aldrich), mixed and incubated at $42^{\circ} \mathrm{C}$ for additional 18-24 h. The overnight culture was also serially diluted and spread onto CHROMagar STEC (CHROMagar) plates for the isolation of STEC. For multiplex PCR detection, the overnight enrichment was used to extract DNA and subjected to multiplex PCR with fluorescent probes targeting for stx1, stx2, and uidA encoding for the $\beta$-D-glucuronidase enzyme for the rapid detection of STEC (Feng et al., 2011). The LOD for STEC is $1 \mathrm{CFU} / \mathrm{g}$.

\section{Detection of Salmonella}

Salmonella spp. were detected by standard culturing method and confirmed by latex agglutination and PCR (FDA, 2011). Briefly, $25 \mathrm{~g}$ of representative samples was homogenized in $225 \mathrm{ml}$ of $\mathrm{BPW}$ and incubated at $35^{\circ} \mathrm{C}$ for $24 \mathrm{~h}$, which was sub-cultured in Rappaport-Vassiliadis (RV, HD) and tetrathionate (TT, BD) broth for selective enrichment at 42 and $35^{\circ} \mathrm{C}$ for $24 \mathrm{~h}$, respectively. The resulting enrichment culture was streaked onto xylose lysine desoxycholate (XLD, HD), bismuth sulfite (BS, HD), hektoen enteric (HE, HD), and CHROMagar Salmonella (CHROMagar) plates and incubated at $35^{\circ} \mathrm{C}$ for $24-48 \mathrm{~h}$. The presumptive positive colonies were confirmed with Salmonella Latex Test (Oxoid Ltd., Hants, UK) and PCR targeting Salmonella invasion gene invA (Rahn et al., 1992; Malorny et al., 2003). A sample is positive when Salmonella is found in any combination of enrichment media and plates. Salmonella positive samples were further subjected to enumeration using three-tube MPN method following published method (Fravalo et al., 2003). The LOD for MPN enumeration is $3 \mathrm{MPN} / \mathrm{g}$.

\section{Detection of $L$. monocytogenes}

L. monocytogenes in the samples was detected by standard plating technique. Briefly, $25 \mathrm{~g}$ of fertilizer, soil, foliage, or fruit sample was homogenized in $225 \mathrm{ml}$ of buffered Listeria enrichment broth (BLEB, BD), non-selectively enriched for $4 \mathrm{~h}$ at $30^{\circ} \mathrm{C}$, followed by additional $24-48 \mathrm{~h}$ of selective enrichment with $10 \mathrm{mg} / \mathrm{L}$ acriflavin, $50 \mathrm{mg} / \mathrm{l}$ cycloheximide (Amresco), and $40 \mathrm{mg} / \mathrm{L}$ nalidixic acid (Sigma-Aldrich). The enrichment culture was streaked onto modified Oxford agar (MOX, BD) and CHROMagar Listeria (CHROMagar) plates. MOX and CHROMagar Listeria plates were incubated at 35 and $37^{\circ} \mathrm{C}$, respectively, for $24-48 \mathrm{~h}$. The presumptive positive colonies were confirmed by PCR targeting invasion-associated secreted endopeptidase (iap) gene (FDA, 2017).

\section{Statistical Analysis}

Quantification data were analyzed by GLM from Statistical Analysis Systems (SAS, Cary, NC). Mean values were compared by least significant difference (LSD) multiple-comparison test. Values of $p$ less than 0.05 were considered significant. Results were reported as mean \pm SEM (standard error of mean).

\section{RESULTS}

\section{Quantification of Indicator Microorganisms}

In 2017, $4.14 \pm 0.08$ and $3.60 \pm 0.10 \log _{10} \mathrm{CFU} / \mathrm{g}$ total coliform were detected in COM and PS, respectively, while those in $\mathrm{CON}, \mathrm{AS}$, and DLE were under detection limit (3 MPN/g) (Figure 2A). Consistent with 2017, total coliform in CON and AS were below the detection limit and that in COM was $3.99 \pm 0.10 \log _{10} \mathrm{CFU} / \mathrm{g}$ (Figure 2B). While indicator microorganisms in DLE, PS, and SL were $2.92 \pm 0.07,0.63 \pm 0.37$, and $3.03 \pm 0.06 \log _{10} \mathrm{CFU} / \mathrm{g}$, respectively, for total coliform, and $2.97 \pm 0.04,0.43 \pm 0.28$, and $2.57 \pm 0.02 \log _{10} \mathrm{CFU} / \mathrm{g}$, respectively for generic $E$. coli (Figures $2 \mathbf{B}, \mathbf{C}$ ).

Total coliform in soil samples before fertilizer application in 2017 study was $4.84 \pm 0.03 \log _{10} \mathrm{CFU} / \mathrm{g}$, and it remained at similar levels throughout the cropping system regardless of fertilizer treatment (Figure 3A). In 2018, however, total coliform in soil samples before fertilizer application was $3.38 \pm 0.04 \log _{10} \mathrm{CFU} / \mathrm{g}$, which increased by $0.4-0.6 \log _{10}$ $\mathrm{CFU} / \mathrm{g}$ right after fertilizer application independent of the 

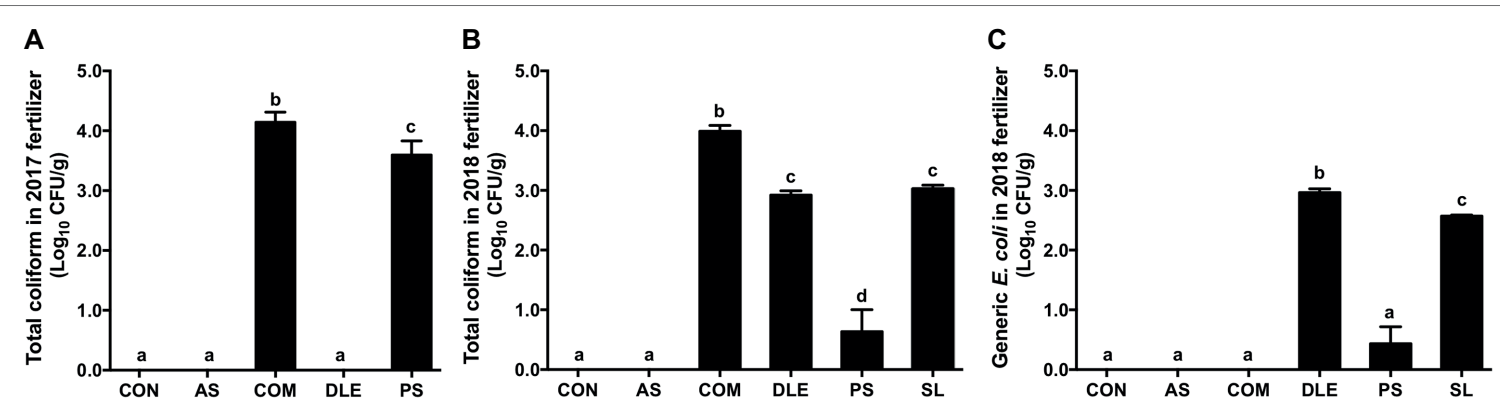

FIGURE 2 | Abundance of total coliform and generic E. coli in fertilizers used in raspberry field 2017-2018. (A) Total coliform counts of fertilizers in 2017; (B) total coliform enumeration of fertilizers in 2018; (C) Generic E. coli enumeration of fertilizers in 2018. Mean \pm SEM, five samples were collected per fertilizer in 2017 and four samples per fertilizer in 2018; $25 \mathrm{~g}$ per sample was tested. Histogram bars without common letter differ significantly $(p<0.05)$. CON: standard fertilization; AS: ammonium sulfate; COM: compost, DLE: digested liquid effluent; PS: phosphorous solid; SL: straight lagoon.

treatment (Figure 3B). Total coliform was further increased in soil samples during the subsequent 2 months and the count increased most in COM while least in DLE (Figure 3B). The total coliform decreased in general over the season; its counts in soil with COM fertilizer were significantly $(p<0.05)$ higher than those in CON group (Figure 3B). Generic $E$. coli counts remained less than $1.0 \log _{10} \mathrm{CFU} / \mathrm{g}$ throughout the season (Figure 3C).

For both cropping seasons, total coliform or generic E. coli counts in foliar samples were lower than $0.4 \log _{10} \mathrm{MPN} / \mathrm{g}$ regardless of fertilizer treatment (Figure 4). Neither total coliform nor generic $E$. coli was detected by the MPN method in raspberry fruit samples for 2 years (data not shown).

\section{Detection of Pathogenic Microorganisms in Fertilizer, Soil, Foliage, and Fruit Samples}

In the 2-year study, no STEC or L. monocytogenes was detected from fertilizer, soil, foliar, or raspberry fruit samples throughout the sampling period (Data not shown). In 2017 cropping season, Salmonella was not detected in soil samples before fertilizer application as well as all soil samples postfertilization except PS (Table 2). Salmonella in soil amended with PS was reduced to undetectable level 2 or 4 months post-application (Table 2). No Salmonella was detected in foliar or raspberry fruit samples (Table 2). In 2018, Salmonella was not detected in fertilizers except SL and DLE (Table 2). MPN enumeration showed that DLE fertilizer contained $55.5 \pm 12.5 \mathrm{MPN} / \mathrm{g}$ of Salmonella while SL fertilizer contained less than detection limit (3 MPN/g) (Table 2). Consistently, Salmonella was detected in soil samples right after amendment with these two fertilizers (Table 2). Salmonella was also detected in soil samples pre-application of DLE or right after application of CON or AS (Table 2). Salmonella populations in all positive soil samples were less than 12 MPN/g (Table 2). In agreement with 2017, no Salmonella was detected in soil samples 2 and 4 months post-fertilizer application, foliar or fruit samples regardless of fertilizer treatments in 2018 (Table 2).

\section{DISCUSSION}

\section{Fecal Indicator Microorganisms in Raspberry Field}

Raw diary manure (SL) in this study contained $\sim 3.0$ and 2.6 $\log _{10}$ CFU/g of total coliform and generic E. coli, respectively. Similarly, harvested cattle manure is reported to carry 3.2 and $2.5 \log _{10} \mathrm{CFU} / \mathrm{g}$ of total coliform and generic E. coli, respectively (Klein et al., 2010). Raw bovine manure collected from another farm contained $\sim 4.2 \log _{10} \mathrm{CFU} / \mathrm{g}$ of generic E. coli (Chiapetta et al., 2019). The US Food and Drug Administration (FDA) requires biological soil amendments of animal origin to contain less than 1,000 MPN ( $3 \log _{10}$ MPN) fecal coliforms per gram or milliliter of total solids after a valid controlled treatment process (FDA, 2018b). All the treated fertilizers tested in this study met the above standard. In support of our finding, $E$. coli in dairy manure was reduced to undetectable levels during composting process (Larney et al., 2003; Grewal et al., 2006). Both solid and liquid of plug-flow anaerobically digested bovine manure contained 1.6-2.5 $\log _{10} \mathrm{CFU/g}$ of generic E. coli (Chiapetta et al., 2019), while another study reported that anaerobically digested dairy manure contained 4.5-5.4 $\log _{10}$ CFU/g of generic E. coli (Saunders et al., 2012).

Soil samples before fertilizer application in 2018 cropping season had $\sim 3.4 \log _{10} \mathrm{CFU} / \mathrm{g}$ total coliform, which was lower than that in 2017, but similar with that of $\sim 2.8 \log _{10} \mathrm{CFU} / \mathrm{g}$ in lettuce field pre-application of farmyard manure (FischerArndt et al., 2010) and $3.4 \log _{10} \mathrm{MPN} / \mathrm{g}$ in untreated soil from vegetable field (Machado et al., 2006). The total coliform level in soil samples was fairly stable across the 2017 cropping season regardless of fertilizer treatment, while it increased with time before harvesting fruit in 2018 and reached a level similar to that of the 2017 season. The exact reason for the observed pattern was uncertain, which might be due to the weather and other environmental factors such as temperature associated with different cropping seasons (Saunders et al., 2012). Generic E. coli in 2018 cropping season remained at less than 1.0 $\log _{10} \mathrm{CFU} / \mathrm{g}$ in soil samples throughout the production season regardless of fertilizer treatments. Similarly, generic E. coli in soil post-application of raw or anaerobically digested dairy 


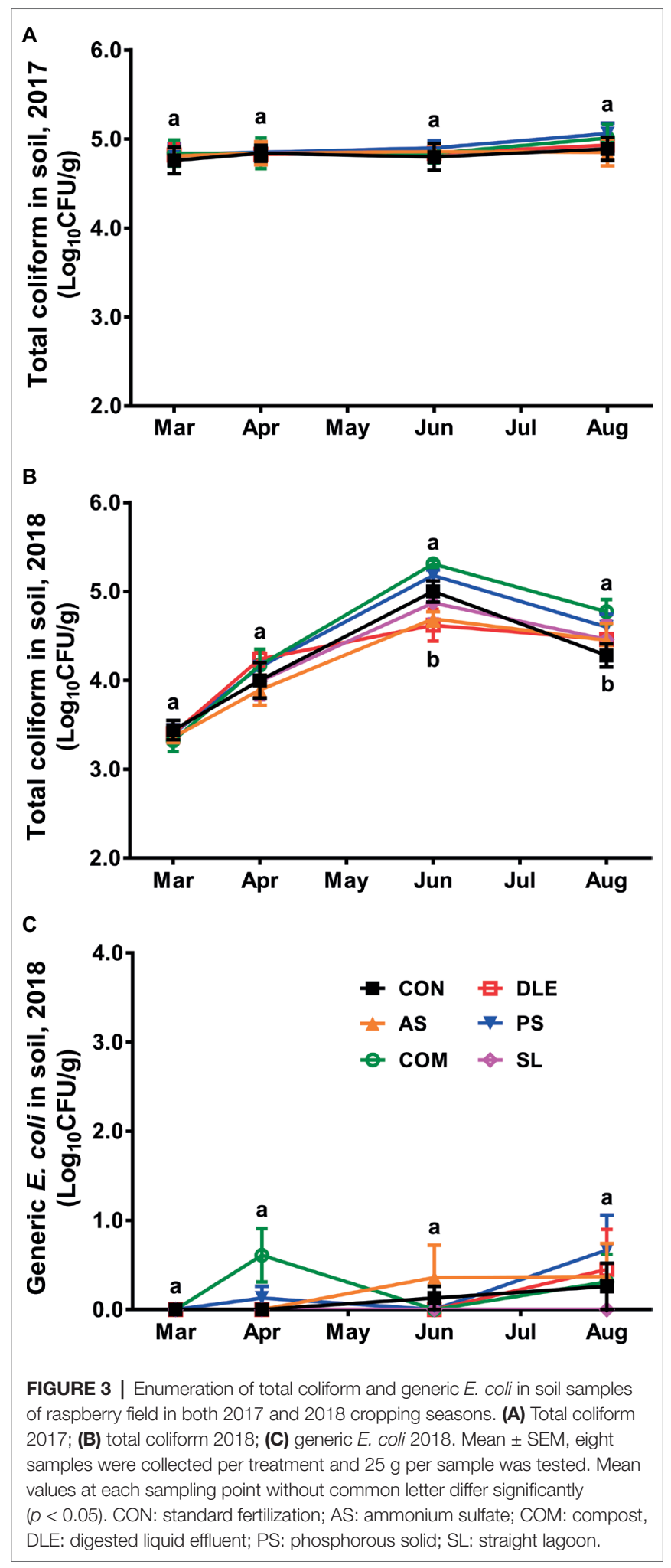

manure stayed at 1.0-2.0 $\log _{10} \mathrm{CFU} / \mathrm{g}$ soil for at least 20 days (Saunders et al., 2012). In contrast to the stable generic $E$. coli level and the increased coliform counts in soil samples collected over the 2018 production season, Salmonella was only detected in soil samples collected pre- and post-fertilizer application. This is consistent with previous finding that generic E. coli is a poor fecal indicator in soil from fresh produce field (Ceuppens et al., 2015). Generic E. coli can be present in non-fecal environment and has the ability to proliferate in the environment (Park et al., 2016; Patterson et al., 2018; Allard et al., 2019). The above evidence collectively reinforces the need to explore a suitable generic fecal indicator microorganism of soil.

\section{Pathogenic Microorganisms in Raspberry Field Shiga Toxin-Producing E. coli}

STEC are frequently involved in deadly fresh produce outbreaks (CDC, 2014, 2018a,b). Both traditional culture-based method and real-time PCR method were carried out to detect STEC from the collected samples during 2017 and 2018 cropping seasons. Traditional culture method takes more than $24 \mathrm{~h}$ to generate results while PCR provides fast and real-time screening. However, naturally occurring PCR inhibitors in environmental samples can impair direct DNA amplification by PCR and lead to false-negative results (Dobhal et al., 2014). Two methods were carried out simultaneously as a comparison. No STEC was detected from the tested fertilizers, indicating the treatments of dairy manure are adequate to eliminate the potential STEC in the respective raw manure. Similarly, E. coli O157:H7 was not detected in the lettuce grown in soil amended with bovine manure-derived fertilizers including firm manure and slurry (Johannessen et al., 2004).

\section{Salmonella}

Salmonella were detected in PS (2017), DLE (2018), and SL (2018) treatments and further transferred to the amended soil samples. In support of our finding, $6.6 \%$ of solid bovine manure collected from dairy farms in California was positive of Salmonella (Chen et al., 2019). Salmonella has been detected in more than $80 \%$ of effluent bovine manure immediately post-commercial anaerobic digestion (Chiapetta et al., 2019). The Salmonella in raw manure (SL) was below our detection limit of $3 \mathrm{MPN} / \mathrm{g}$ while DLE was $55.5 \pm 12.5 \mathrm{MPN} / \mathrm{g}$, higher than the microbial standard of 3 MPN/4 g for treated manure (FDA, 2018b). A recent study reported that Salmonella in raw dairy manure ranged from less than 3 $\log _{10} \mathrm{CFU} / \mathrm{g}$ to $5.2 \log _{10} \mathrm{CFU} / \mathrm{g}$ (Chen et al., 2019). Farm-scale psychrophilic anaerobic digester only reduced Salmonella by 1.2-1.4 $\log _{10} \mathrm{CFU} / \mathrm{g}$ in swine manure (initial Salmonella population ranged from less than 2.0 to $4.7 \log _{10} \mathrm{CFU} / \mathrm{g}$ ), resulting in fair amount of Salmonella remaining in the effluent manure (Masse et al., 2011). In contrast, thermophilic and mesophilic anaerobic digesters reduced Salmonella in raw cattle manure from 1,000-1,500 MPN/g to less than $1 \mathrm{MPN} / \mathrm{g}$ (Harikishan and Sung, 2003).

Salmonella was also detected in two of the soil samples pre-application of DLE and one of the soil samples post-application of CON and AS treatments, which were free from Salmonella, in the 2018 cropping season. It has been reported that $2.6 \%$ of 617 soil/sediment samples collected from a major produce region in California was positive of Salmonella (Gorski et al., 2011). Another study also showed that Salmonella was detected in $2.2 \%$ of 178 soil samples collected from five produce farms in New York State (Strawn et al., 2013). The uneven distribution 

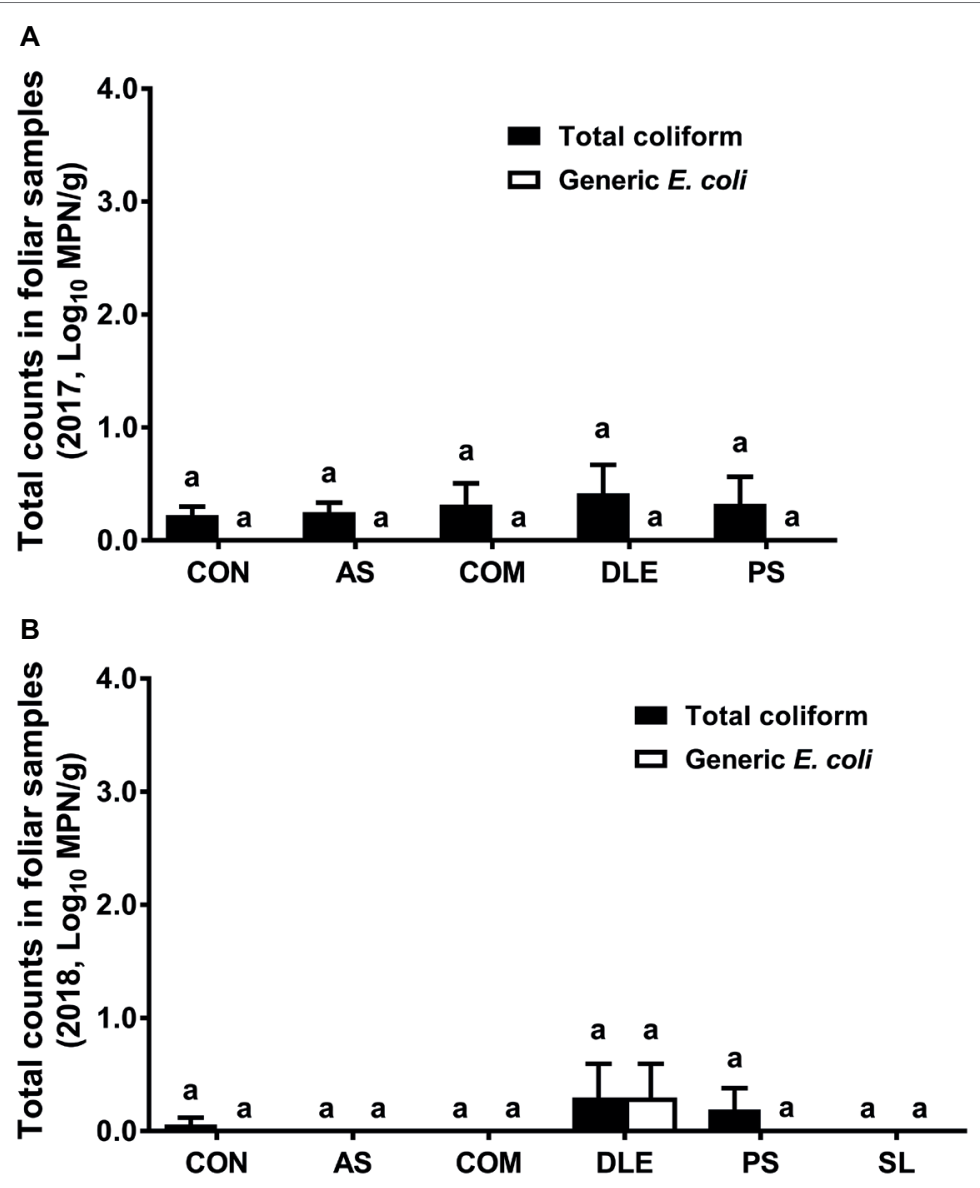

FIGURE 4 | Most probable number of total coliform and generic E. coli in foliar samples from raspberry field in both 2017 and 2018 cropping seasons. (A) Total coliform and generic E. coli in 2017; (B) total coliform and generic E. coli in 2018. Mean \pm SEM, 12 samples were collected per treatment in 2017 and eight samples per treatment in 2018, while $25 \mathrm{~g}$ per sample was analyzed. Histogram bars without common letter differ significantly $(p<0.05)$. CON: standard fertilization; AS: ammonium sulfate; COM: compost, DLE: digested liquid effluent; PS: phosphorous solid; SL: straight lagoon. MPN: most probable number.

TABLE 2 | Detection of Salmonella in raspberry field in 2017-2018 production seasons. ${ }^{a}$

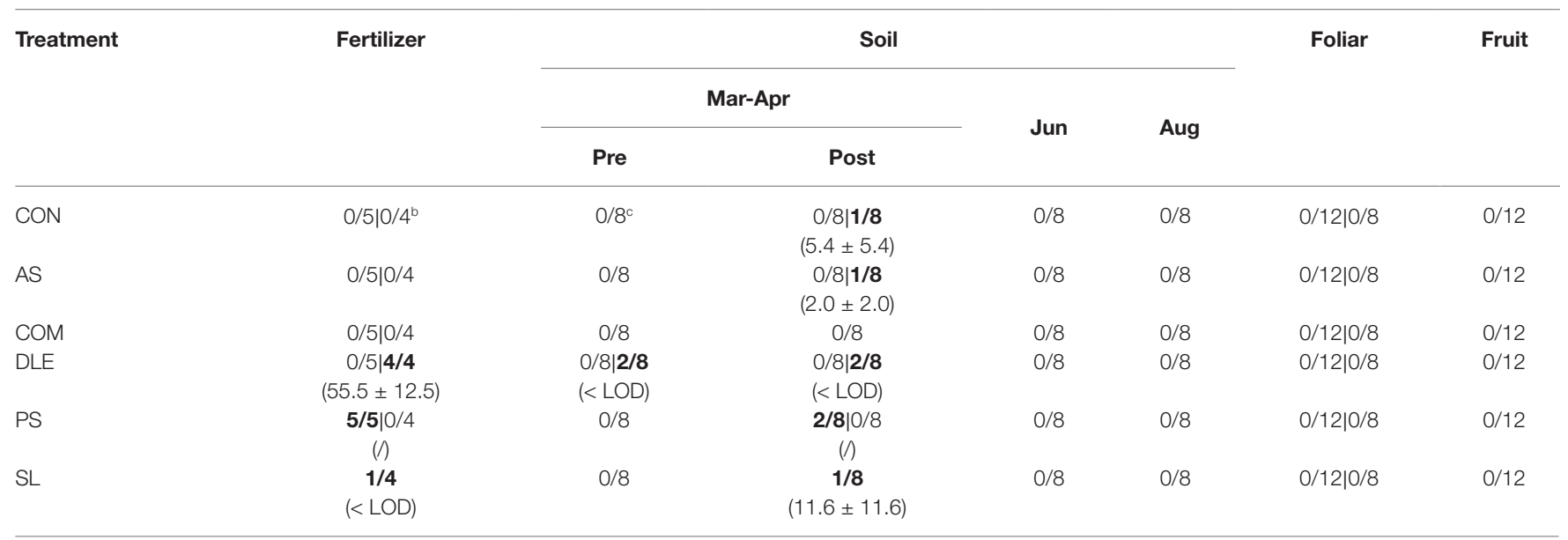

${ }^{a}$ Results were confirmed by Latex Salmonella and PCR detection of invA gene;

${ }^{b}$ Positive samples/total samples per treatment in 2017|Positive samples/total samples per treatment in 2018 [enumeration of Salmonella in positive samples using most probable number (MPN), expressed in MPN/g, Mean \pm SEM, LOD: limit of detection, 3 MPN/g; /: not enumerated].

¿2017 and 2018 production season with the same result was only reported once.

CON: standard fertilization; AS: ammonium sulfate; COM: compost; DLE: digested liquid effluent; PS: phosphorous solid; SL: straight lagoon; Pre: pre-application of fertilizer; Post: post-application of fertilizer. Jun: soil was sampled in June before fruit harvest; Aug: soil was sampled in August after fruit harvest. 
of Salmonella in soil might contribute to our observation. It could also be due to the transmission through aerosol in highwind condition, wild animals, or stormwater runoff (Baertsch et al., 2007; Silva et al., 2014). Salmonella was below detectable level in soil samples 2 and 4 months post-fertilizer application, foliar, or raspberry fruit samples in both cropping seasons. In support of our finding, Salmonella contaminated in soil at $\sim 3.0$ $\log _{10}$ CFU/g survived for less than 2 months (Nicholson et al., 2005). Lettuce grew in soil contaminated with $\sim 4.0 \log _{10} \mathrm{CFU} / \mathrm{g}$. $S$. Typhimurium was negative of Salmonella even though Salmonella was still detectable in the soil samples at lettuce sampling (Franz et al., 2005). However, S. Typhimurium at an initial contamination level of $\sim 7.0 \log _{10} \mathrm{CFU} / \mathrm{g}$ persisted in soil for more than 5 months, and was detected in lettuce and parsley that grew in this contaminated soil (Islam et al., 2004b).

\section{L. monocytogenes}

In this study, no L. monocytogenes was detected from any of the collected samples in both cropping seasons. Our result indicated that the current dairy manure treatments adequately minimized the potential risk of introducing L. monocytogenes to raspberry production system. In support of our finding, $L$. monocytogenes was not detected from treated bovine or human waste, soil, or vegetables (tomato, radish, carrot, cucumber, pepper, and lettuce) in field trials (Johannessen et al., 2004; Brochier et al., 2012; Rahube et al., 2014).

\section{CONCLUSION}

Based on 2 years of field studies conducted in 2017 and 2018 raspberry cropping system, application of raw dairy manure straight lagoon (SL), anaerobically digested dairy manure liquid effluent (DLE), aerobically composted dairy manure (COM), and refined anaerobically digested dairy manure products including ammonium sulfate (AS) and phosphorous solid (PS) had no major impacts on indicator microorganisms including

\section{REFERENCES}

Allard, S. M., Callahan, M. T., Bui, A., Ferelli, A. M. C., Chopyk, J., Chattopadhyay, S., et al. (2019). Creek to table: tracking fecal indicator bacteria, bacterial pathogens, and total bacterial communities from irrigation water to kale and radish crops. Sci. Total Environ. 666, 461-471. doi: 10.1016/j.scitotenv.2019.02.179

Baertsch, C., Paez-Rubio, T., Viau, E., and Peccia, J. (2007). Source tracking aerosols released from land-applied class B biosolids during high-wind events. Appl. Environ. Microbiol. 73, 4522-4531. doi: 10.1128/AEM.02387-06

Benedict, C., Harrison, J., Hall, S.A., and Yorgey, G. (2018). Nutrient recovery: products from dairy manure to improve soil fertility. Available at: http:// cru.cahe.wsu.edu/CEPublications/FS305E/FS305E.pdf (Accessed August 2, 2019).

Beuchat, L. R. (2002). Ecological factors influencing survival and growth of human pathogens on raw fruits and vegetables. Microbes Infect. 4, 413-423. doi: 10.1016/S1286-4579(02)01555-1

Brochier, V., Gourland, P., Kallassy, M., Poitrenaud, M., and Houot, S. (2012). Occurrence of pathogens in soils and plants in a long-term field study regularly amended with different composts and manure. Agric. Ecosyst. Environ. 160, 91-98. doi: 10.1016/j.agee.2011.05.021

Carter, M. R., and Stewart, B. A. (1995). Structure and organic matter storage in agricultural soils. Boca Raton, FL: CRC Press. total coliform and generic E. coli as well as the major foodborne pathogens including STEC, Salmonella, and L. monocytogenes in red raspberry production system in Lynden sandy loam. Application of raw dairy manure or its derivatives once per season 4 months pre-harvest did not introduce microbiological safety risk to red raspberry production under good agricultural practices.

\section{DATA AVAILABILITY STATEMENT}

All datasets generated for this study are included in the manuscript/supplementary files.

\section{AUTHOR CONTRIBUTIONS}

LS, XS, YS, and H-CT performed the microbial experiment. LS wrote the manuscript. CB and ES collected samples for microbial analyses. M-JZ, LS, CK, and CB designed the study. $\mathrm{M}-\mathrm{JZ}, \mathrm{CK}, \mathrm{CB}$, and $\mathrm{MD}$ revised the manuscript.

\section{FUNDING}

Research activities were funded by USDA-NRCS\#693A7516020, and Washington State Departmental of Agriculture (WSDA) K1516, K1811, and K2308.

\section{ACKNOWLEDGMENTS}

The authors appreciate the generous support from Randy Honcoop Farm in conducting this study and thank Beth Chisholm, Jessica Shaw, and Kolten Kirkendoll for sample collection for microbial analysis and Drs. Xia Song and Yang He and Oscar R. Ulloa for their assistance in microbial sample preparation and analysis.

CDC (2011). Multistate outbreak of Listeriosis linked to whole cantaloupes from Jensen Farms, Colorado. Available at: http://www.cdc.gov/listeria/ outbreaks/cantaloupes-jensen-farms/082712/ (Accessed August 23, 2018).

CDC (2012). Multistate outbreak of Salmonella Typhimurium and Salmonella Newport infections linked to Cantaloupe (final update). Available at: http:// www.cdc.gov/salmonella/typhimurium-cantaloupe-08-12/ (Accessed August 23, 2018).

CDC (2014). Multistate outbreak of Shiga toxin-producing Escherichia coli O121 infections linked to raw clover sprouts (final update). Available at: https:// www.cdc.gov/ecoli/2014/o121-05-14/index.html (Accessed August 7, 2019).

CDC (2018a). Multistate outbreak of E. coli O157:H7 infections linked to romaine lettuce (final update). Available at: https://www.cdc.gov/ecoli/2018/ o157h7-04-18/index.html (Accessed August 7, 2019).

CDC (2018b). Multistate outbreak of Shiga toxin-producing Escherichia coli O157:H7 infections linked to leafy greens (final update). Available at: https:// www.cdc.gov/ecoli/2017/o157h7-12-17/index.html (Accessed August 7, 2019).

Ceuppens, S., Johannessen, G. S., Allende, A., Tondo, E. C., El-Tahan, F., Sampers, I., et al. (2015). Risk factors for Salmonella, Shiga toxin-producing Escherichia coli and Campylobacter occurrence in primary production of leafy greens and strawberries. Int. J. Environ. Res. Public Health 12, 9809-9831. doi: 10.3390/ijerph120809809 
CFIA (2017). Food recall warning-raspberry mousse cakes recalled due to norovirus. Available at: http://www.inspection.gc.ca/about-the-cfia/newsroom/food-recallwarnings/complete-listing/2017-08-11/eng/1502504278989/1502504282052 (Accessed March 16, 2019).

CFR (2019). \$205.203 Soil fertility and crop nutrient management practice standard. Available at: https://www.ecfr.gov/cgi-bin/text-idx?SID=5b54f57ac35 925f92ec258714e838791\&mc=true\&node=se7.3.205_1203\&rgn=div8 (Accessed August 2, 2019).

Chen, Z., Biswas, S., Aminabadi, P., Stackhouse, J. W., Jay-Russell, M. T., and Pandey, P. K. (2019). Prevalence of Escherichia coli O157 and Salmonella spp. in solid bovine manure in California using real-time quantitative PCR. Lett. Appl. Microbiol. 69, 23-29. doi: 10.1111/lam.13156

Chiapetta, H., Harrison, J., Gay, J., McClanahan, R., Whitefield, E., Evermann, J., et al. (2019). Reduction of pathogens in bovine manure in three full-scale commercial anaerobic digesters. Water Air Soil Pollut. 230:111. doi: 10.1007/ s11270-019-4163-4

Danyluk, M. D., Fatica, M. K., Brar, P. K., McEgan, R., Valadez, A. M., Schneider, K. R., et al. (2013). Fruits and vegetables. Washington, DC: APHA Press.

Dobhal, S., Zhang, G., Rohla, C., Smith, M. W., and Ma, L. M. (2014). A simple, rapid, cost-effective and sensitive method for detection of Salmonella in environmental and pecan samples. J. Appl. Microbiol. 117, 1181-1190. doi: 10.1111/jam.12583

Eissenberger, K., Moench, D., Drissner, D., Weiss, A., and Schmidt, H. (2018). Adherence factors of enterohemorrhagic Escherichia coli O157:H7 strain Sakai influence its uptake into the roots of Valerianella locusta grown in soil. Food Microbiol. 76, 245-256. doi: 10.1016/j.fm.2018.05.016

EPA (2012). Fecal bacteria. Available at: https://archive.epa.gov/water/archive/ web/html/vms511.html (Accessed March 16, 2019).

EPA (2014). USEPA/USGS sample collection protocol for bacterial pathogens in surface soil. Available at: https://cfpub.epa.gov/si/si_public_record_report.cfm ?dirEntryId=285571\&Lab=NHSRC\&fed_org_id $=1253 \&$ subject $=$ Homeland + Sec urity + Research \&view $=$ desc \&sortBy $=$ pubDateYear\&count $=25 \&$ showCriteria $=1 \&$ searchall=biological+and+soil\&submit=Search (Accessed November 26, 2018).

FDA (2002). BAM 4: enumeration of Eschierchia coli and the coliform bacteria. Available at: https://www.fda.gov/Food/FoodScienceResearch/LaboratoryMethods/ ucm064948.htm (Accessed November 26, 2018).

FDA (2010). BAM appendix 2: most probable number from serial dilutions. Available at: https://www.fda.gov/Food/FoodScienceResearch/LaboratoryMethods/ ucm109656.htm (Accessed November 26, 2018).

FDA (2011). Bacteriological analytical manual, chapter 5: Salmonella. Available at: https://www.fda.gov/Food/FoodScienceResearch/LaboratoryMethods/ucm 070149.htm (Accessed November 27, 2018).

FDA (2014). FDA investigates Listeria monocytogenes illnesses linked to caramel apples. Available at: http://www.cdc.gov/salmonella/typhimurium-cantaloupe-08-12/ (Accessed September 3, 2018).

FDA (2017). BAM: detection and enumeration of Listeria monocytogenes. Available at: https://www.fda.gov/Food/FoodScienceResearch/LaboratoryMethods/ucm 071400.htm (Accessed November 27, 2018).

FDA (2018a). 21CFR112.54. Available at: https://www.accessdata.fda.gov/scripts/ cdrh/cfdocs/cfCFR/CFRSearch.cfm?fr=112.54 (Accessed August 2, 2019).

FDA (2018b). 21CFR112.55. Available at: https://www.accessdata.fda.gov/scripts/ cdrh/cfdocs/cfCFR/CFRSearch.cfm?fr=112.55 (Accessed August 2, 2019).

FDA (2019a). Alma Pak voluntarily recalls frozen blackberries due to possible health risk of Norovirus. Available at: https://www.fda.gov/safety/recallsmarket-withdrawals-safety-alerts/alma-pak-voluntarily-recalls-frozenblackberries-due-possible-health-risk-norovirus (Accessed July 23, 2019).

FDA (2019b). FSMA final rule on produce safety. Available at: https://www. fda.gov/Food/GuidanceRegulation/FSMA/ucm334114.htm (Accessed August 2, 2019).

FDA (2019c). Winco Foods, LLC. Recalls frozen red raspberries because of possible health risk. Available at: https://www.fda.gov/safety/recalls-marketwithdrawals-safety-alerts/winco-foods-llc-recalls-frozen-red-raspberriesbecause-possible-health-risk (Accessed July 23, 2019).

Feng, P., Weagant, S., and Jinneman, K. (2011). Bacteriological analytical manual, chapter 4A, diarrheagenic Escherichia coli. Available at: http://www.fda.gov/ Food/FoodScienceResearch/LaboratoryMethods/ucm070080.htm (Accessed January 21, 2019).

Fischer-Arndt, M., Neuhoff, D., Tamm, L., and Kopke, U. (2010). Effects of weed management practices on enteric pathogen transfer into lettuce (Lactuca sativa var. capitata). Food Control 21, 1004-1010. doi: 10.1016/j. foodcont.2009.12.019

Forge, T., Walters, T., and Koch, C. (2014). Use of composted dairy manure solids mulch for raspberry: influences on soil nematode communities and $\mathrm{N}$ and $\mathrm{P}$ availability. Compost Sci. Util. 22, 230-241. doi: 10.1080/1065657X.2014.930677

Franz, E., van Diepeningen, A. D., de Vos, O. J., and van Bruggen, A. H. C. (2005). Effects of cattle feeding regimen and soil management type on the fate of Escherichia coli O157: H7 and Salmonella enterica serovar Typhimurium in manure, manure-amended soil, and lettuce. Appl. Environ. Microbiol. 71, 6165-6174. doi: 10.1128/AEM.71.10.6165-6174.2005

Fravalo, P., Hascoet, Y., Le Fellic, M., Queguiner, S., Petton, J., and Salvat, G. (2003). Convenient method for rapid and quantitative assessment of Salmonella enterica contamination: the mini-MSRV MPN technique. J. Rapid Methods Autom. Microbiol. 11, 81-88. doi: 10.1111/j.1745-4581.2003.tb00031.x

Gorski, L., Parker, C. T., Liang, A., Cooley, M. B., Jay-Russell, M. T., Gordus, A. G., et al. (2011). Prevalence, distribution, and diversity of Salmonella enterica in a major produce region of California. Appl. Environ. Microbiol. 77, 2734-2748. doi: 10.1128/AEM.02321-10

Grant, J., Wendelboe, A. M., Wendel, A., Jepson, B., Torres, P., Smelser, C., et al. (2008). Spinach-associated Escherichia coli O157: H7 outbreak, Utah and New Mexico, 2006. Emerg. Infect. Dis. 14, 1633-1636. doi: 10.3201/ eid1410.071341

Grewal, S. K., Rajeev, S., Sreevatsan, S., and Michel, F. C. (2006). Persistence of Mycobacterium avium subsp paratuberculosis and other zoonotic pathogens during simulated composting, manure packing, and liquid storage of dairy manure. Appl. Environ. Microbiol. 72, 565-574. doi: 10.1128/AEM.72.1.565-574.2006

Grewal, S., Sreevatsan, S., and Michel, F. C. (2007). Persistence of Listeria and Salmonella during swine manure treatment. Compost Sci. Util. 15, 53-62. doi: 10.1080/1065657X.2007.10702311

Harikishan, S., and Sung, S. W. (2003). Cattle waste treatment and class A biosolid production using temperature-phased anaerobic digester. Adv. Environ. Res. 7, 701-706. doi: 10.1016/S1093-0191(02)00034-5

Herwaldt, B. L., Ackers, M. L., Farrar, J., Richardson, S., Nelson, R., Fletcher, M., et al. (1997). An outbreak in 1996 of cyclosporiasis associated with imported raspberries. N. Engl. J. Med. 336, 1548-1556. doi: 10.1056/NEJM199705293362202

Hirneisen, K. A., Sharma, M., and Kniel, K. E. (2012). Human enteric pathogen internalization by root uptake into food crops. Foodborne Pathog. Dis. 9, 396-405. doi: 10.1089/fpd.2011.1044

Ho, A. Y., Lopez, A. S., Eberhart, M. G., Levenson, R., Finkel, B. S., da Silva, A. J., et al. (2002). Outbreak of cyclosporiasis associated with imported raspberries, Philadelphia, Pennsylvania, 2000. Emerg. Infect. Dis. 8, 783-788. doi: 10.3201/ eid0808.020012

Hutchison, M. L., Walters, L. D., Avery, S. M., Munro, F., and Moore, A. (2005). Analyses of livestock production, waste storage, and pathogen levels and prevalences in farm manures. Appl. Environ. Microbiol. 71, 1231-1236. doi: 10.1128/AEM.71.3.1231-1236.2005

Hutchison, M. L., Walters, L. D., Avery, S. M., Synge, B. A., and Moore, A. (2004). Levels of zoonotic agents in British livestock manures. Lett. Appl. Microbiol. 39, 207-214. doi: 10.1111/j.1472-765X.2004.01564.x

Islam, M., Doyle, M. P., Phatak, S. C., Millner, P., and Jiang, X. P. (2004a). Persistence of enterohemorrhagic Escherichia coli O157: H7 in soil and on leaf lettuce and parsley grown in fields treated with contaminated manure composts or irrigation water. J. Food Prot. 67, 1365-1370. doi: 10.4315/0362-028x-67.7.1365

Islam, M., Doyle, M. P., Phatak, S. C., Millner, P., and Jiang, X. (2005). Survival of Escherichia coli O157: H7 in soil and on carrots and onions grown in fields treated with contaminated manure composts or irrigation water. Food Microbiol. 22, 63-70. doi: 10.1016/j.fm.2004.04.007

Islam, M., Morgan, J., Doyle, M. P., Phatak, S. C., Millner, P., and Jiang, X. (2004b). Persistence of Salmonella enterica serovar Typhimurium on lettuce and parsley and in soils on which they were grown in fields treated with contaminated manure composts or irrigation water. Foodborne Pathog. Dis. 1, 27-35. doi: 10.1089/153531404772914437

Jechalke, S., Schierstaedt, J., Becker, M., Flemer, B., Grosch, R., Smalla, K., et al. (2019). Salmonella establishment in agricultural soil and colonization of crop plants depend on soil type and plant species. Front. Microbiol. 10:967. doi: 10.3389/fmicb.2019.00967

Johannessen, G. S., Froseth, R. B., Solemdal, L., Jarp, J., Wasteson, Y., and Rorvik, L. M. (2004). Influence of bovine manure as fertilizer on the 
bacteriological quality of organic iceberg lettuce. J. Appl. Microbiol. 96, 787-794. doi: 10.1111/j.1365-2672.2004.02208.x

Klein, M., Brown, L., Tucker, R. W., Ashbolt, N. J., Stuetz, R. M., and Roser, D. J. (2010). Diversity and abundance of zoonotic pathogens and indicators in manures of feedlot cattle in Australia. Appl. Environ. Microbiol. 76, 6947-6950. doi: 10.1128/AEM.01095-10

Larney, F. J., Yanke, L. J., Miller, J. J., and McAllister, T. A. (2003). Fate of coliform bacteria in composted beef cattle feedlot manure. J. Environ. Qual. 32, 1508-1515. doi: 10.2134/jeq2003.1508

Machado, D. C., Maia, C. M., Carvalho, I. D., da Silva, N. F., Andre, M. C. D. P. B., and Serafini, A. B. (2006). Microbiological quality of organic vegetables produced in soil treated with different types of manure and mineral fertilizer. Braz. J. Microbiol. 37, 538-544. doi: 10.1590/S1517-83822006000400025

Macori, G., Gilardi, G., Bellio, A., Bianchi, D. M., Gallina, S., Vitale, N., et al. (2018). Microbiological parameters in the primary production of berries: a pilot study. Foods 7:E105. doi: 10.3390/foods7070105

Malorny, B., Hoorfar, J., Bunge, C., and Helmuth, R. (2003). Multicenter validation of the analytical accuracy of Salmonella PCR: towards an international standard. Appl. Environ. Microbiol. 69, 290-296. doi: 10.1128/ AEM.69.1.290-296.2003

Masse, D., Gilbert, Y., and Topp, E. (2011). Pathogen removal in farm-scale psychrophilic anaerobic digesters processing swine manure. Bioresour. Technol. 102, 641-646. doi: 10.1016/j.biortech.2010.08.020

Miller, B. D., Rigdon, C. E., Robinson, T. J., Hedberg, C., and Smith, K. E. (2013). Use of global trade item numbers in the investigation of a Salmonella Newport outbreak associated with blueberries in Minnesota, 2010. J. Food Prot. 76, 762-769. doi: 10.4315/0362-028X.JFP-12-407

Mootian, G., Wu, W. H., and Matthews, K. R. (2009). Transfer of Escherichia coli O157:H7 from soil, water, and manure contaminated with low numbers of the pathogen to lettuce plants. J. Food Prot. 72, 2308-2312. doi: 10.4315/0362-028X-72.11.2308

Natvig, E. E., Ingham, S. C., Ingham, B. H., Cooperband, L. R., and Roper, T. R. (2002). Salmonella enterica serovar Typhimurium and Escherichia coli contamination of root and leaf vegetables grown in soils with incorporated bovine manure. Appl. Environ. Microbiol. 68, 2737-2744. doi: 10.1128/ AEM.68.6.2737-2744.2002

Nicholson, F. A., Groves, S. J., and Chambers, B. J. (2005). Pathogen survival during livestock manure storage and following land application. Bioresour. Technol. 96, 135-143. doi: 10.1016/j.biortech.2004.02.030

Park, Y., Pachepsky, Y., Shelton, D., Jeong, J., and Whelan, G. (2016). Survival of manure-borne Escherichia coli and fecal coliforms in soil: temperature dependence as affected by site-specific factors. J. Environ. Qual. 45, 949-957. doi: $10.2134 /$ jeq2015.08.0427

Patterson, L., Navarro-Gonzalez, N., Jay-Russell, M. T., Aminabadi, P., Antaki-Zukoski, E., and Pires, A. F. A. (2018). Persistence of Escherichia coli in the soil of an organic mixed crop-livestock farm that integrates sheep grazing within vegetable fields. Zoonoses Public Health 65, 887-896. doi: $10.1111 /$ zph. 12503

Rahn, K., Degrandis, S. A., Clarke, R. C., McEwen, S. A., Galan, J. E., Ginocchio, C., et al. (1992). Amplification of an invA gene sequence of Salmonella Typhimurium by polymerase chain reaction as a specific method of detection of Salmonella. Mol. Cell. Probes 6, 271-279. doi: 10.1016/0890-8508(92)90002-F

Rahube, T. O., Marti, R., Scott, A., Tien, Y. C., Murray, R., Sabourin, L., et al. (2014). Impact of fertilizing with raw or anaerobically digested sewage sludge on the abundance of antibiotic-resistant coliforms, antibiotic resistance genes, and pathogenic bacteria in soil and on vegetables at harvest. Appl. Environ. Microbiol. 80, 6898-6907. doi: 10.1128/Aem.02389-14

Rechcigl, J. E. (1995). Soil amendments and environmental quality. Boca Raton, FL: CRC Press.

Resende, J. A., Silva, V. L., de Oliveira, T. L., de Oliveira Fortunato, S., da Costa Carneiro, J., Otenio, M. H., et al. (2014). Prevalence and persistence of potentially pathogenic and antibiotic resistant bacteria during anaerobic digestion treatment of cattle manure. Bioresour. Technol. 153, 284-291. doi: 10.1016/j.biortech.2013.12.007

Sarvikivi, E., Roivainen, M., Maunula, L., Niskanen, T., Korhonen, T., Lappalainen, M., et al. (2012). Multiple norovirus outbreaks linked to imported frozen raspberries. Epidemiol. Infect. 140, 260-267. doi: 10.1017/ S0950268811000379

Saunders, O., Harrison, J., Fortuna, A. M., Whitefield, E., and Bary, A. (2012). Effect of anaerobic digestion and application method on the presence and survivability of E. coli and fecal coliforms in dairy waste applied to soil. Water Air Soil Pollut. 223, 1055-1063. doi: 10.1007/s11270-011-0923-5

Silva, C., Calva, E., and Maloy, S. (2014). One health and food-borne disease: Salmonella transmission between humans, animals, and plants. Microbiol. Spectr. 2:OH-0020-2013. doi: 10.1128/microbiolspec.OH-0020-2013

Sobsey, M. D., Khatib, L. A., Hill, V. R., Alocilja, E., and Pillai, S. (2006). Pathogens in animal wastes and the impacts of waste management practices on their survival, transport and fate. Animal Agriculture and the Environment: National Center for Manure and Animal Waste Management White Papers. pp. 609-666.

Strawn, L. K., Fortes, E. D., Bihn, E. A., Nightingale, K. K., Grohn, Y. T., Worobo, R. W., et al. (2013). Landscape and meteorological factors affecting prevalence of three food-borne pathogens in fruit and vegetable farms. Appl. Environ. Microbiol. 79, 588-600. doi: 10.1128/AEM.02491-12

Tefera, T., Tysnes, K. R., Utaaker, K. S., and Robertson, L. J. (2018). Parasite contamination of berries: risk, occurrence, and approaches for mitigation. Food Waterborne Parasitol. 10, 23-38. doi: 10.1016/j.fawpar.2018.04.002

Wilkie, A. C. (2005). "Anaerobic digestion of dairy manure: design and process considerations" in Dairy manure management: Treatment, handling, and community relations (Natural Resouce, Agriculture, and Engineering Service) (Ithaca, NY: Cornell University), 301-312.

Xu, W. Q., and Wu, C. Q. (2016). The impact of pulsed light on decontamination, quality, and bacterial attachment of fresh raspberries. Food Microbiol. 57, 135-143. doi: 10.1016/j.fm.2016.02.009

Zebarth, B., Neilsen, G., Hogue, E., and Neilsen, D. (1999). Influence of organic waste amendments on selected soil physical and chemical properties. Can. J. Soil Sci. 79, 501-504. doi: 10.4141/S98-074

Conflict of Interest: The authors declare that the research was conducted in the absence of any commercial or financial relationships that could be construed as a potential conflict of interest.

Copyright (c) 2019 Sheng, Shen, Benedict, Su, Tsai, Schacht, Kruger, Drennan and Zhu. This is an open-access article distributed under the terms of the Creative Commons Attribution License (CC BY). The use, distribution or reproduction in other forums is permitted, provided the original author(s) and the copyright owner(s) are credited and that the original publication in this journal is cited, in accordance with accepted academic practice. No use, distribution or reproduction is permitted which does not comply with these terms. 